\title{
The Teacher-Student Relationship in Han Yu's On Teachers and Its Educational Significance
}

\author{
Li Xiaohui $^{1}$ \\ Depart. of Education \\ Pusan National University \\ Busan, South Korea 46241 \\ lixiaohui2016@naver.com
}

\author{
Changun Park ${ }^{2}$ \\ Dept. of Education \\ Pusan National University \\ Busan, South Korea 46241 \\ cupark@pusan.ac.kr
}

\begin{abstract}
Recently, there are unfortunate episodes between teachers and students. We could see an endless number of reports about related extreme events caused by deterioration of teacherstudent relationship. The purpose of present study is to analyze the teacher-student relationship in On Teachers (Shi Shuo) containing Han Yu's educational thoughts, and to figure out the main problems and the prime reasons of the deteriorated relationship between teachers and students, hoping to obtain educational enlightenment for teacher-student relationship construction and improvement. To achieve the purpose, we mainly adopt literature research methods. From what has been discussed, we may safely draw the conclusion that to establish an ideal teacher-student relationship can't be separated from teacher-student interaction in teaching and learning, equal twoway communication, ethics followed by the two sides and healthy education environment. In addition, we also need to approach teacher-student relationship in a developing view.
\end{abstract}

Keywords-Han Yu; On Teachers; Teacher-Student Relationship; Educational Significance

\section{INTRODUCTION}

In general, the basic elements of education include educators, educatees and education material being the contact intermediary of educators and educatees, which are interdependent and interactive with each other. As the most basic and core relationship in the school education teachinglearning activities, the relationship between teachers and students is unnegligible with its important influence on promoting talent training and the development of education, receiving wide attention among education field. Teacherstudent relationship can have a lasting impact on the development of students. Teachers who have strong bonds with their students have been shown to be more effective in their teaching roles. In addition to lower levels of behavioral problems, teachers with strong classroom bonds are also able to achieve higher levels of academic success among students.

In particular, China is actively promoting the basic education reform, and the construction of great relationship between teachers and students plays an important role in the healthy and harmonious development of the whole education career. However, from time to time, there are unfortunate episodes happened between teachers and students. We could see an endless number of reports about related extreme events caused by deterioration of teacher-student relationship. The lopsided relationship between teachers and students becomes difficult to embody in a single sentence.

In ancient times of China and other countries, many scholars and educators have left many insightful comments on construction of the relationship between teachers and students. As a famous article by $\mathrm{Han} \mathrm{Yu}$, a famous writer, philosopher and thinker of Tang dynasty in China, <On Teachers> is the first book in the history of Chinese education devoted to teachers and teaching. Han Yu set up the example of being a teacher by his solemn and just attitude without being affected by others and stood up for the teacher, which played a positive role in correcting the vulgar social atmosphere of "being shameful for seeking for a teacher".

At present, China is in the critical period of education reform of comprehensive promoting quality, and the teacherstudent relationship is directly related to the development of talent training and the whole education career. The teacherstudent relationship advocated by $O n$ Teachers is still of great significance today.

\section{THE TEACHER-STUDENT RELATIONSHIP IN $O N$ TEACHERS}

The discussion on the teacher-student relationship in <On Teachers>: breaks the traditional conservative barrier of teachers' law, and puts forward the teacher-student relationship in a reasonable and equal way, which was of positive significance in the feudal society of the time."'[1] The teacher-student relationship advocated by $\mathrm{Han} \mathrm{Yu}$ can be summarized in the following two aspects:

Firstly, "one was not born to know everything, who can claim to have no doubts? If one has doubts and is not willing to learn from a teacher, his doubts will never be resolved." People were not born to understand everything and everyone could be confused. But if people do not follow the teacher when they feel confused, the doubt will probably remain forever unsolved. Han $\mathrm{Yu}$ affirmed the necessity of acquired learning and the importance of teachers answering questions and doubts, encouraging students to learn from teachers with an open mind. 
Secondly, "a student is not necessarily inferior to his teacher, nor does a teacher necessarily be more virtuous and talented than his student. The real fact is that one might have learned the doctrine earlier than the other, or might be a master in his own special field." Students are not necessarily inferior to teachers and teachers are not necessarily sager than students. It is merely a matter of time and their own strengths. Specifically, we can acquire understanding from the following three dimensions.

In the first instance, "a student is not necessarily inferior to his teacher." The fundamental purpose of education is to promote human development and student's learning is also upward and progressive. As time going on, the width and depth of knowledge learned by student will be further developed and even surpass his teacher. Han Yu fully affirmed the unlimited possibilities of students in the process of continuous development and also advocated that students should dare to surpass teachers.

In the next place, "nor does a teacher necessarily be more virtuous and talented than his student." That is to say, even a knowledgeable teacher cannot know everything and be proficient in everything because of the limitations of the profession and other aspects. Han Yu denied that the absolute authority of teachers can not be changed, so the teacher can not be satisfied with their current knowledge and must continue to learn to supplement the perfect themselves along with the advance and updating of knowledge.

Again, "the real fact is that one might have learned the doctrine earlier than the other, or might be a master in his own special field." Which is, due to the time and discipline difference of learning, the teacher may master more knowledge before students in some areas, but with the expansion of the learning time, depth and breadth, students may grasp more knowledge than teachers. Han Yu figured that both students and teachers were developing people and were at the stage of development, and also, the identity of students and teachers was not absolutely the same but was relatively and two-way, which could be mutual transformed. Teachers and students can both be students and teachers, learning from each other and making progress together.

\section{MAIN PROBLEMS IN TEACHER-STUDENT RELATIONSHIP}

In the era of knowledge economy, the traditional teacherstudent relationship has undergone unprecedented changes. The main problems in teacher-student relationship are mainly as follows.

Firstly, the ambiguity of the rights and obligations of teachers and students. Many teachers still stick to the traditional absolute dominance, pursuing a top-down model of knowledge instilling and forbidding students to challenge their authority with sharp language and stateliness, which makes students appear daunting at first. In the long run, it can risk and easily lead to a tendency of abusing powers.

Secondly, the communication barrier between teachers and students. Teachers and students belong to two generations, and there is an insurmountable age gap and a completely different thinking mode between teachers and students. "The communication between teachers and students is not limited to the exchange of knowledge, but more about the exchange of ideas and emotions. Through the interaction, they can accept and integrate with each other, making the teaching-learning activities more smooth."[2] Teachers are always accustomed to seeing students from the perspective of adults, and students do not understand the expression of teachers, giving rise to communication barriers between teachers and students.

Thirdly, the utilitarian relationship between teachers and students. It is true that students' score is an influencing factor in evaluating teachers, but not a slam dunk by any stretch. Some teachers take scores as a standard measuring students and determine their attitude towards students based on students' scores with preference towards high-scoring students and indifference towards low-scoring students. There are even many students flatter and cater to teachers pleasure because of the fear of teachers' authority for more favour from teachers. "The factors of affection and friendship between teachers and students are fading, while the economic and utilitarian factors are increasing." [3]

\section{MAIN REASONS FOR THE DETERIORATION OF TEACHER- STUDENT RELATIONSHIP}

Facing with the increasingly cold and distant teacherstudent relationship, the main reasons are as follows:

Firstly, exam-oriented education and scoring theory are main reasons for the deterioration of teacher-student relationship. Under the exam-oriented education system, teachers focus on if students' learning will get high scores and students focus on if teachers' teaching can make themselves get high scores. The pursuit of high scores becomes the priority of teachers, students and parents' focus. On the one hand, under the pressure of teaching and examination, teachers are very strict with students, adopting excessive assignments tactic and mechanical repetition training to help students to get high scores. On the other hand, students are burdened with heavy homework and great pressure of college entrance examination pressure. They are greatly constrained and have no time or freedom of their own. Over time, teacher-student relationship becomes estranged.

Secondly, the direct reason for the deterioration of teacherstudent relationship is moral abnormality and emotional apathy. "The only source of students' respect for teachers is their virtue and talent." [4] Teacher's virtue and talent are the spiritual lifeblood of education, which deeply affects students' future and destiny. Be worthy of the name of teacher, teachers should have the good moral quality and professional level. However, facing work pressure of the scores, graduation rates, title evaluation, teaching evaluation and daily necessities of life pressure, teachers are often overstretched, which inevitably leads to psychological burden. Due to various pressures produced by negative emotions, such as loneliness, helplessness, depression and negative psychology, teachers cannot get along with students wholeheartedly. Moreover, some teachers even bring this kind of negative mind into when facing the students with impatience, scolding and physical punishment and so on. However, "good teaching is charged with positive emotion. It is not just a matter of knowing one's 
subject, being efficient, having correct competencies, or learning all the right techniques. Good teachers are not just well oiled machines. They are emotional, passionate beings who connect with their students and fill their work and classes with pleasure, creativity, challenge and joy."[5] The teacherstudent relationship is getting more and more distant before of the loss of the norm of morality and the emotional indifference.

Thirdly, the changing social environment is the catalyst for the deterioration of teacher-student relationship. With the rapid development of knowledge economy, all aspects of social life have undergone tremendous changes and are in a state of changes. This has brought unprecedented impact on the behavior, ideology and value orientation of different generations of teachers and students, and aggravated the deterioration of teacher-student relationship.

\section{THE ENLIGHTENMENT OF HAN YU'S <ON TEACHERS >}

The teacher-student relationship elaborated in Han Yu's <On Teachers> is of great significance to construction and improvement of contemporary teacher-student relationship.

Firstly, things are constantly changing and developing and we should treat problems and teacher-student relationship with a developmental perspective. The essence of education is to promote human development. Teachers and students are not static appearances, but constantly changing and developing. Truth is not absolute, and no one can get things done once and rest forever. Teachers are not the absolute authority of knowledge, but have a slight advantage over students in some aspects. While promoting students' development, teachers should constantly accept new knowledge and improve their professional ability. Student is not only the recipient of knowledge, but has more development potential than teachers in many ways. When paying attention to their own development at the same time, students should also dare to question and surpass on the basis of respect for teachers.

Secondly, teaching benefits teachers as well as students, the ideal teacher-student relationship should make improvement together while teaching and learning. The teaching and learning process between teachers and students is two-way instead of the absolute one-way. As the ancient Chinese goes, "learning will make people know their weakness and teaching will make people understand their confusion. Knowing the weakness to reflect and knowing the confusion will be stronger".[6]Through the practice of teaching and learning process, teachers and students know each other's lack of knowledge and confusion to achieve the harmony of progress of teaching and learning through continuous interaction and feedback.

Thirdly, the communication between teachers and students is the collision between the heart, the communication between soul and the dialogue between minds. "The true education is the activity of hearts, only when it comes from the heart, can it reaches the heart deep.'[7]In the past teaching activities, students' autonomy and the interaction between teachers are not emphasized when teachers teach and students listen. Teachers and students should break the traditional the shackles of educators and educatees and build the dialogical teacher- student relationship of equality, trust, love and humility on the basis of two-way communication by mutual respect and trust between each other. Only when teachers care about students and students understand teachers can they have a deeper exchange of ideas and reach consensus. "By having a supportive relationship with teachers, students will be motivated, will feel protected and this sense of security and friendship will create an empathy which is important to get students interested and desirable to succeed."[8]

Fourthly, nothing can be accomplished without norms or standards. Moral conduct is quite necessary. Meng $\mathrm{Zi}$ once said, "when Yi taught people to shoot an arrow, he would pull the bow till its fullest and the educatees would try to do the same. When a great craftsman teaches, he teaches by rules and educatees learn by rules." [9] In the face of the current conflict-prone teacher-student relationship, it is very important to suggest the moral code of conduct under joint constraints. As the main body of teaching-learning activities, teachers and students should also participate in the establishment of common moral norms and codes of conduct on the basis of the original moral norms.

Fifthly, a healthy education environment is of great benefit A positive and healthy education teaching environment can not only stimulate students' learning pleasure, but also promote teachers' professional growth. When in the positive health education environment, it is easier for students to accept the teacher's emotional and psychological suggestion and teachers to gain career satisfaction from students' affirmation, which can also avoid the tense conflict between teachers and students. The influence of environment is just like life-giving spring breeze, effected imperceptibly and unconsciously, and the positive and healthy education environment is conducive to the establishment of an ideal teacher-student relationship.

\section{CONCLUSION}

"The ideal teacher-student relationship should not only be established on the basic of moral requirements and professional knowledge of being a teacher, but also have the responsibility attribute of teaching, instructing and dispeling doubt." [10] The construction of the ideal teacher-student relationship cannot be separated from teacher-student interaction, equal two-way communication, abiding by the moral standards together and a healthy education environment.

After learning from the past, Han Yu's <On Teachers> contains more positive education views and ideas, which is still of great significance for reference today when actively promoting the development and reform of education. As educators, we should take its essence, inherit and develop its positive education thoughts, and make efforts to build a harmonious relationship between teachers and students and promote the development of the whole education career. 


\section{REFERENCES}

[1] M. Peng. The View of Teacher-Student Relationship in <Shishuo> and Its Modern Enlightenments. Journal of Shayang Teachers College, Vol.10, No.3, pp.13-15. June 2009. (In Chinese)

[2] L. H. Xia. Teacher-Student Relationship at Universities Needs to Be Reconstructed. Guangming Daily, pp. 13, 4th July 2017. (In Chinese)

[3] Y. P. Fang. Main Causes for Distortion of University Teacher-Student Relationship. Journal of China University of Mining \& Technology (Social Science), No.3, pp.78-82.September 2007. (In Chinese)

[4] L. Y. XU, B. H. Li and Z. L. Zhao. Anthology of Einstein. Beijing, The Commercial Press, December 2009. (In Chinese)

[5] Hargreaves, A. Changing teachers, changing times: Teacher's work and culture in the postmodern age. New York: Teachers College Press. 1994.

[6] S. L. Gao. Chinese Educational Classics Series: Learning and Memorizing. Beijing: People's Education Press, March 2016. (In Chinese)

[7] C. Q. Xu. Bridge of Successful Teaching: Dialogue between Teachers and Students. Journal of Hunan First Normal College, Vol.5, No.4, pp.46-48, Decemeber 2005. (In Chinese)

[8] Fredson Soares dos Reis da Luz. The Relationship between Teachers and Students in the Classroom: Communicative Language Teaching Approach and Cooperative Learning Strategy to Improve Learning. U.S.A.: Bridgewater State University, May 2015.

[9] B. J. Yang, F. B. Yang. Mencius (book), Shangcha: Yuelu Press, May 2011. ( In Chinese)

[10] C. L. Gui. To Correct the Lopsided Teacher-Student Relationship. People's Daily, 2018-01-22, pp.5. (In Chinese) 